\title{
PERFORMA PERTUMBUHAN DAN PRODUKTIVITAS IKAN MAS STRAIN MUSTIKA PADA UJI MULTI LOKASI
}

\author{
Didik Ariyanto\#, Yogi Himawan, Khairul Syahputra, Flandrianto Sih Palimirmo, dan Suharyanto \\ Balai Riset Pemuliaan Ikan \\ Jl. Raya 2 Sukamandi, Patokbeusi, Subang. 41263
}

(Naskah diterima: 10 September 2019; Revisi final: 16 September 2019; Disetujui publikasi: 16 September 2019)

\begin{abstract}
ABSTRAK
Ikan mas Mustika merupakan varietas unggul ikan mas hasil seleksi tahan penyakit Koi Herpes Virus (KHV). Secara laboratoris, uji tantang ikan mas Mustika dengan KHV menghasilkan sintasan lebih dari 90\% Namun demikian, performa ikan mas Mustika di lingkungan budidaya terkait pertumbuhan dan tingkat produktivitasnya belum banyak dikaji. Penelitian ini bertujuan mengevaluasi performa ikan mas Mustika sebagai varietas unggul tahan KHV di beberapa lokasi sentra budidaya. Penelitian dilakukan di kolam air deras (KAD) di Tanjungsiang, Subang; serta karamba jaring apung (KJA) di Waduk Jatiluhur, Purwakarta; Waduk Cirata, Cianjur; dan Waduk Darma, Kuningan. Sebagai pembanding digunakan ikan mas Majalaya yang berasal dari unit pembenihan rakyat (UPR) setempat. Penelitian dilakukan dengan tiga kali ulangan selama 90 hari. Hasil penelitian menunjukkan bahwa performa ikan mas lebih dipengaruhi oleh faktor lingkungan daripada faktor genetik, serta interaksi kedua faktor tersebut. Hasil penelitian juga menunjukkan bahwa kualitas perairan di Waduk Darma lebih rendah dibanding lokasi lainnya. Di lokasi tersebut, ikan mas Mustika mempunyai pertumbuhan, produktivitas, dan rasio konversi pakan sebesar 2,81\% $\mathrm{m}^{2}$; dan 1,43 secara nyata lebih baik daripada varietas pembanding, sebesar 2,21\%/hari; 8,16 kg/m²; dan 2,54. Di lokasi lainnya, performa ikan mas Mustika tidak berbeda nyata dengan varietas pembanding. Hal ini mengindikasikan bahwa ikan mas Mustika mempunyai toleransi yang lebih baik terhadap kondisi lingkungan perairan yang buruk, daripada varietas pembanding.
\end{abstract}

\section{KATA KUNCl: ikan mas Mustika; multi lokasi; performa budidaya}

ABSTRACT: Growth and productivity performances of common carp, strain Mustika cultured in a multilocation conditions. By: Didik Ariyanto, Khairul Syahputra, Yogi Himawan, Flandrianto Sih Palimirmo, and Suharyanto

Mustika is the newly produced superior variety of common carp strains resistant to Koi Herpes Virus (KHV). The challenge test of Mustika common carp against KHV resulted in a survival rate of more than $90 \%$ However, the information on the growth and productivity of Mustika common carp in culture conditions is not yet available to supplement its superior resistance to KHV. This study was aimed to evaluate the performance of M ustika as a superior variety of common carp resistant to KHV resistance through multi-location tests which were in: running water ponds (KAD) in Tanjungsiang, Subang; floating net cages (KJA) in Jatiluhur Reservoir, Purwakarta; Cirata Reservoir, Cianjur; and Darma Reservoir, Kuningan. In all trial locations, Majalaya carp from the local hatchery (UPR) were used as the comparison population. The study was conducted for 90 days with three replications. The result showed that the performance of the carp was more affected by the environmental factor than both genetic and interaction of genetic $><$ environment factors. In Darma reservoir which has poorer water quality conditions, Mustika common carp had better growth, productivity and food conversion ratio of $2.81 \%$ day, $13.42 \mathrm{~kg} / \mathrm{m2}$, and 1.43 , respectively, compared to that of the comparison population of $2.21 \%$ day, $8.16 \mathrm{~kg} / \mathrm{m} 2$, and 2.54 . Among the locations used in the multilocation test, the performances of Mustika common carp and the comparison population were not significantly different. These results indicate that Mustika common carp is more tolerant of being cultured in poorer water quality conditions

\section{KEYWORDS: cultured performance; multi-location; Mustika common carp}

\footnotetext{
\# Korespondensi: Balai Riset Pemuliaan Ikan. Jl. Raya 2

Sukamandi, Patokbeusi, Subang. 41263, Indonesia.

Tel. + 62260520500

E-mail: didik_ski@yahoo.com
} 


\section{PENDAHULUAN}

Pengembangan budidaya ikan mas mengalami hambatan signifikan sejak timbulnya wabah penyakit yang disebabkan oleh virus Koi Herpes Virus (KHV) pada sekitar tahun 2002 (Sunarto et al., 2005). Wabah penyakit tersebut mengakibatkan usaha budidaya ikan mas mengalami penurunan yang sangat drastis. Kerugian yang ditimbulkan penyakit KHV pada tahun 2002 mencapai lebih dari US\$10.000.000 (Rukmono, 2005).

Beberapa pendekatan yang telah dilakukan antara lain melalui penerapan manajemen kesehatan ikan secara terpadu, penggunaan ikan mas bebas KHV, aplikasi imunopropilaksis, dan lain-lain (Taukhid et al., 2005). Namun demikian, upaya penanggulangan penyakit yang dilakukan belum memperoleh hasil yang signifikan. Strategi alternatif penanggulangan penyakit KHV lainnya adalah melalui perbaikan genetik ikan mas, sehingga lebih tahan terhadap penyakit tersebut. Hasil dari kegiatan perbaikan genetik tersebut adalah strain Mustika yang tahan terhadap KHV. Strain Mustika telah dirilis untuk kegiatan budidaya berdasarkan Surat Keputusan Menteri Kelautan dan Perikanan No. 24/ KEPMEN-KP/2016.

Ikan mas Mustika merupakan strain unggul ikan mas yang diperoleh melalui kegiatan seleksi berbasis marka molekuler (Marker Assisted Selection). Marka genetik molekuler yang digunakan dalam kegiatan seleksi individu ikan mas pada karakter daya tahan terhadap KHV adalah gen MHC-II (Major Histocompatibility Complex), khususnya pada alel Cyca-DAB-1*05 (Syahputra et al., 2016). Gen ini mengolah dan menyajikan potongan-potongan mikroba asing yang sudah dihancurkan di permukaan sel terinfeksi sehingga mudah dikenali oleh sistem imun (Rakus et al., 2008). Adanya pengenalan ini, tubuh ikan menjadi lebih siap menghadapi serangan patogen sehingga secara fisiologi lebih tahan terhadap penyakit. Ikan mas Mustika mempunyai ketahanan terhadap penyakit KHV dengan sintasan pada uji tantang sebesar $98,89 \%$ (Syahputra et al., 2016).

Berdasarkan hasil uji tantang secara laboratorium, ikan mas Mustika mempunyai daya tahan yang baik terhadap penyakit KHV. Namun, performa ikan mas Mustika di lingkungan budidaya terkait laju petumbuhan, produksi pada saat panen, nilai konversi pakan, dan lain-lain belum banyak dilaporkan. Penelitian ini bertujuan mengevaluasi performa ikan mas Mustika di beberapa lokasi budidaya berbeda.

\section{BAHAN DAN METODE}

\section{Ikan Uji}

Ikan uji dalam penelitian ini adalah ikan mas Mustika yang berasal dari Balai Riset Pemuliaan Ikan (BRPI), Sukamandi. Ikan uji adalah generasi F-3 yang diseleksi dari hasil perkawinan betina F-2 dan jantan F-3. Prosedur pembentukan ikan uji pada penelitian ini mengikuti Ariyanto et al. (2019). Sebagai pembanding digunakan ikan mas Majalaya yang diperoleh dari pembenih di sekitar lokasi pengujian (unit pembenihan rakyat/UPR). Umur kedua populasi benih pada saat penebaran adalah dua bulan setelah menetas dengan ukuran panjang badan $12,05 \pm 1,34$ $\mathrm{cm}$ dan bobot badan 14,28 \pm 4,44 g/ekor.

\section{Metode dan Lokasi Pengujian}

Rancangan percobaan yang digunakan adalah rancangan factorial dua faktor, yaitu jenis genotipe dan lokasi pengujian. Genotipe yang digunakan terdiri atas dua strain, yaitu strain Mustika dan Majalaya. Lokasi pengujian terdiri atas tiga lokasi, yaitu kolam air deras (KAD) di Tanjungsiang, Kabupaten Subang dan karamba jaring apung (KJA) masing-masing di Waduk Jatiluhur, Kabupaten Purwakarta; Waduk Cirata, Kabupaten Cianjur; dan Waduk Darma, Kabupaten Kuningan. Lokasi pengujian berada pada elevasi yang berbeda-beda. Kolam air deras di Tanjungsiang, Kabupaten Subang berada pada ketinggian $\pm 700 \mathrm{~m}$ dpl, Waduk Jatiluhur, Kabupaten Purwakarta pada ketinggian 110 m dpl; Waduk Cirata, Kabupaten Cianjur pada ketinggian $220 \mathrm{~m}$ dpl; dan Waduk Darma, Kabupaten Kuningan pada ketinggian 715 m dpl.

Kolam air deras di Tanjungsiang berukuran $3 \mathrm{~m} \mathrm{x}$ $15 \mathrm{~m} \times 2,5 \mathrm{~m}$ ditebar benih ikan mas dengan kepadatan 7.500 ekor/kolam. Ukuran karamba jaring apung yang digunakan di tiga lokasi adalah $7 \mathrm{~m} \times 7 \mathrm{~m} \times 3 \mathrm{~m}$. Padat penebaran benih ikan mas di Waduk Cirata dan Waduk Darma sebanyak 5.000 ekor/petak, sedangkan di Waduk Jatiluhur sebanyak 7.500 ekor/petak. Selama 90 hari masa pengujian, benih ikan mas diberi pakan pelet tenggelam dengan kandungan protein kasar sebesar 28\%30\%secara ad libitum. Jumlah penggunaan pakan dicatat setiap pekan, dan diakumulasikan pada akhir kegiatan.

\section{Analisis Data dan Evaluasi}

Analisis performa ikan mas di semua lokasi pengujian dilakukan pada akhir kegiatan. Semua benih ikan mas dipanen dan dilakukan pengukuran beberapa 
parameter budidaya, meliputi bobot dan panjang akhir rata-rata individu, laju pertumbuhan spesifik, sintasan, biomassa pada saat panen, dan rasio konversi pakan. Data yang diperoleh dianalisis menggunakan ANOVA faktorial untuk melihat pengaruh genotipe, lingkungan, dan interaksi antara kedua faktor tersebut terhadap performa ikan uji. Jika hasilnya berbeda nyata, analisis dilanjutkan menggunakan uji Duncan (DMRT) pada taraf kepercayaan 95\%

Sebagai data dukung, dilakukan analisis parameter kualitas air media budidaya di masing-masing lokasi, meliputi tingkat kecerahan, suhu, kandungan oksigen terlarut, nilai pH, amoniak, dan nitrit. Analisis kualitas air dilakukan setiap satu bulan sekali menggunakan alat digital quality water checker, kecuali parameter kandungan amoniak dan nitrit dilakukan dengan membawa sampel air dari lokasi pengujian dan dianalisis di Laboratorium Kualitas Air Balai Riset Pemuliaan Ikan (BRPI) Sukamandi. Pengukuran dan pengambilan sampel air dilakukan di tiga titik berbeda dari setiap unit percobaan. Data parameter kualitas air media budidaya dianalisis dan disajikan secara deskriptif.

\section{HASIL DAN BAHASAN}

\section{Pengaruh Genetik, Lingkungan, dan Interaksinya}

Hasil analisis varian (ANOVA) terhadap parameterparameter performa ikan uji disajikan pada Tabel 1. Berdasarkan Tabel 1 terlihat bahwa lingkungan atau lokasi budidaya mempunyai pengaruh terhadap performa ikan maslebih besar dibandingkan faktor genetik. Keenam parameter terkait performa budidaya ikan masyang dianalisis secara nyata dipengaruhi oleh kondisi lingkungan budidaya. Dalam penelitian ini, interaksi faktor genetik dengan lingkungan tidak berpengaruh nyata terhadap performa ikan mas yang diuji.

Hasil analisis ini sejalan dengan pernyataan Purdom (1993) dan Tave (1993) bahwa performa ikan mas sangat dipengaruhi oleh kondisi lingkungan pemeliharaan. Pernyataan tersebut didukung oleh penelitian yang dilakukan oleh Linhart et al. (2002) yang menyatakan bahwa pengaruh lingkungan pemeliharaan merupakan faktor utama yang berpengaruh terhadap performa ikan mas, sedangkan pengaruh faktor genetikrelatif lebih kecil. Ditambahkan oleh Wang \& Li (2007) bahwa pengaruh interaksi genetik dengan lingkungan pada pemeliharaan ikan mas sangat kecil. Hasil penelitian ini mengindikasikan bahwa kondisi lingkungan merupakan faktor sangat penting dalam kegiatan budidaya ikan mas.Meskipun tidak sebesar pengaruh lingkungan, penggunaan strain unggul seperti ikan mas Mustika juga memengaruhi performa budidaya ikan mas.

\section{Performa Budidaya Ikan Mas}

Hasil analisis Ianjutan terhadap performa pertumbuhan dan parameter budidaya ikan mas di masing-masing lokasi disajikan pada Tabel 2. Hasil analisis pada Tabel 2 menunjukkan bahwa performa pertumbuhan dan parameter budidaya ikan mas Mustika secara nyata lebih baik daripada ikan mas pembanding di Waduk Darma. Namun, performa ikan mas Mustika dan ikan mas pembanding tidak berbeda nyata di ketiga lokasi pengujian lainnya.

Lebih cepatnya laju pertumbuhan ikan mas Mustika dibanding ikan mas Majalaya di Waduk Darma diduga disebabkan oleh dua hal. Pertama, ikan mas Mustika merupakan benih hasil seleksi, sedangkan ikan mas

Tabel 1. Analisis varian genotipe, lingkungan, dan interaksi genotipe dengan lingkungan $(G><E)$ pada pengujian budidaya ikan mas Mustika

Table 1. Analysis of variance of genotype, environment, and genotype $><$ environment interaction of common carp trial

\begin{tabular}{lcccccc}
\hline \multicolumn{1}{c}{$\begin{array}{c}\text { Karakter } \\
\text { Characters }\end{array}$} & $\begin{array}{c}\text { KT genotipe F-hit genotipe } \\
\text { KT genotype }\end{array}$ & $\begin{array}{c}\text { KT lingkungan } \\
\text { F-hit genotype }\end{array}$ & $\begin{array}{c}\text { KT environment } \\
\text { F-hit lingkungan } \\
\text { F-hit environment }\end{array}$ & KT G $><$ E F-Hit G $><$ E \\
\hline Pertumbuhan (Growth) & 0.7 & $14.0^{*}$ & 0,7 & $13,0^{*}$ & 0,1 & $1,0^{\text {ns }}$ \\
Bobot (Weight) & $11,434.8$ & $4.5^{*}$ & $21,559.5$ & $8.5^{*}$ & 986.8 & $0.4^{\text {ns }}$ \\
Panjang (Length) & $5,044.4$ & $1,8^{\text {ns }}$ & $56,700.8$ & $20.4^{*}$ & 13 & $0.0^{\text {ns }}$ \\
Sintasan (Survival rate) & 45.4 & $0.5^{\text {ns }}$ & $2,204.9$ & $23.7^{*}$ & 51 & $0.6^{\text {ns }}$ \\
Biomassa (Biomass) & 216,902 & $3.9^{*}$ & $362,487.5$ & $6.6^{*}$ & $10,183.5$ & $0.2^{\text {ns }}$ \\
Konversi pakan (Feed conversion ) & 1 & $2.2^{*}$ & 2.7 & $5.9^{*}$ & 0.3 & $0.7^{\text {ns }}$ \\
\hline
\end{tabular}

Keterangan (Note): * berpengaruh nyata berdasarkan uji $\mathrm{F}$ pada $\alpha 0,05 ; \mathrm{ns}=$ tidak berpengaruh nyata berdasarkan uji $\mathrm{F}$ pada $\alpha 0,05 ; \mathrm{KT}=$ kuadrat tengah 
Tabel 2. Parameter budidaya ikan mas menggunakan varietas Mustika dan Majalaya selama 90 hari di empat lokasi yang berbeda

Tabel 2. Measured culture parameters of strain Mustika and Majalaya during 90 days of the multi-locations test

\begin{tabular}{|c|c|c|c|c|c|}
\hline \multirow[b]{2}{*}{$\begin{array}{l}\text { Strain ikan } \\
\text { Strain of fish }\end{array}$} & \multirow[b]{2}{*}{$\begin{array}{l}\text { Parameter budidaya } \\
\text { Culture parameters }\end{array}$} & \multicolumn{4}{|c|}{ Lokasi uji (Trial location ) } \\
\hline & & $\begin{array}{c}\text { KJA Jatiluhur } \\
\text { Jatiluhur net cage }\end{array}$ & $\begin{array}{c}\text { KJA Cirata } \\
\text { Cirata net cage }\end{array}$ & $\begin{array}{c}\text { KAD Tanjungsiang } \\
\text { Tanjungsiang running water }\end{array}$ & $\begin{array}{l}\text { KJA Darma } \\
\text { Darma net cage }\end{array}$ \\
\hline \multirow{6}{*}{$\begin{array}{l}\text { Ikan mas Mustika } \\
\text { Mustika carp }\end{array}$} & $\begin{array}{l}\text { Bobot akhir } \\
\text { Final weight }(\mathrm{g})\end{array}$ & $312.56 \pm 71.58^{\mathrm{a}}$ & $279.90 \pm 61.91^{a}$ & $231.84 \pm 31.75^{\mathrm{a}}$ & $180.96 \pm 36.28^{a}$ \\
\hline & $\begin{array}{l}\text { Pertumbuhan (\%hari) } \\
\text { Growth (\%day) }\end{array}$ & $3.41 \pm 0.25^{\mathrm{a}}$ & $3.29 \pm 0.25^{\mathrm{a}}$ & $3.09 \pm 0.15^{\mathrm{a}}$ & $2.81 \pm 0.22^{a}$ \\
\hline & $\begin{array}{l}\text { Sintasan } \\
\text { Survival rate }(\%)\end{array}$ & $31.67 \pm 9.50^{a}$ & $75.00 \pm 7.00^{a}$ & $70.00 \pm 7.00^{\mathrm{a}}$ & $75.00 \pm 13.23^{\mathrm{a}}$ \\
\hline & $\begin{array}{l}\text { Biomassa } \\
\text { Biomass }(\mathrm{kg})\end{array}$ & $775.54 \pm 398.04^{\mathrm{a}}$ & $1,055.98 \pm 277.23^{a}$ & $1,208.96 \pm 103.78^{a}$ & $671.12 \pm 120.96^{\mathrm{a}}$ \\
\hline & $\begin{array}{l}\text { Konversi pakan } \\
\text { Food conversion }\end{array}$ & $2.43 \pm 1.46^{\mathrm{a}}$ & $1.71 \pm 0.54^{\mathrm{a}}$ & $1.35 \pm 0.13^{\mathrm{a}}$ & $1.43 \pm 0.32^{a}$ \\
\hline & $\begin{array}{l}\text { Produktivitas } \\
\text { Productivity }\left(\mathrm{kg} / \mathrm{m}^{2}\right)\end{array}$ & $15.51 \pm 7.96^{\mathrm{a}}$ & $21.12 \pm 5.54^{\mathrm{a}}$ & $24.18 \pm 2.08^{a}$ & $13.42 \pm 2.42^{\mathrm{a}}$ \\
\hline \multirow{6}{*}{$\begin{array}{l}\text { Ikan mas Majalaya } \\
\text { Majalaya carp }\end{array}$} & $\begin{array}{l}\text { Bobot akhir } \\
\text { Final weight }(\mathrm{g})\end{array}$ & $266.30 \pm 62.81^{\mathrm{a}}$ & $224.88 \pm 40.06^{a}$ & $224.67 \pm 58.34^{\mathrm{a}}$ & $114.79 \pm 8.97^{b}$ \\
\hline & $\begin{array}{l}\text { Pertumbuhan (\%hari) } \\
\text { Growth (\%day) }\end{array}$ & $3.13 \pm 0.26^{a}$ & $2.95 \pm 0.20^{\mathrm{a}}$ & $2.93 \pm 0.31^{a}$ & $2.21 \pm 0.31^{b}$ \\
\hline & $\begin{array}{l}\text { Sintasan } \\
\text { Survival rate }(\%)\end{array}$ & $35.33 \pm 6.43^{a}$ & $74.67 \pm 5.03^{a}$ & $60.00 \pm 15.00^{\mathrm{a}}$ & $70.67 \pm 9.50^{a}$ \\
\hline & $\begin{array}{l}\text { Biomassa } \\
\text { Biomass }(\mathrm{kg})\end{array}$ & $703.81 \pm 210.82^{a}$ & $841.37 \pm 168.27^{a}$ & $997.74 \pm 317.45^{a}$ & $408.15 \pm 85.40^{b}$ \\
\hline & $\begin{array}{l}\text { Konversi pakan } \\
\text { Food conversion }\end{array}$ & $2.45 \pm 0.73^{a}$ & $1.99 \pm 0.46^{\mathrm{a}}$ & $1.79 \pm 0.59^{\mathrm{a}}$ & $2.54 \pm 0.60^{b}$ \\
\hline & $\begin{array}{l}\text { Produktivitas } \\
\text { Productivity }\left(\mathrm{kg} / \mathrm{m}^{2}\right)\end{array}$ & $14.08 \pm 4.22^{a}$ & $16.83 \pm 3.37^{a}$ & $19.95 \pm 6.35^{\mathrm{a}}$ & $8.16 \pm 1.71^{b}$ \\
\hline
\end{tabular}

Keterangan: Huruf superskrip yang berbeda pada parameter dan kolom yang sama menunjukkan berbeda nyata pada $\alpha 0,05$ Note: Different superscripts on the same parameter and in the same column showed significant differences at $\alpha 0.05$

Majalaya yang digunakan sebagai pembanding adalah ikan yang berasal dari unit pembenihan rakyat (UPR), yang tidak melalui program seleksi. Meskipun ikan mas Mustika merupakan ikan mas hasil seleksi marka terkait karakter ketahanan terhadap penyakit KHV, tetapi dalam pelaksanaanya juga diiringi dengan seleksi pada karakter pertumbuhan (Ariyanto et al., 2014). Dugaan kedua adalah adanya peningkatan daya toleransi ikan mas Mustika terhadap kualitas lingkungan perairan yang rendah. Peningkatan daya toleransi tersebut diduga sebagai dampak dari peningkatan ketahanan terhadap infeksi penyakit pada populasi ikan mas tersebut.
Meskipun nilai sintasan ikan mas Mustika tidak berbeda nyata dengan benih ikan mas Majalaya di semua lokasi pengujian, namun laju pertumbuhan yang secara nyata lebih cepat mengakibatkan bobot akhir, biomassa, dan produktivitas ikan mas Mustika di Waduk Darma secara nyata lebih baik dibanding ikan mas Majalaya. Selain unggul dalam beberapa karakter tersebut, ikan mas Mustika juga mampu memanfaatkan pakan yang diberikan dengan lebih baik. $\mathrm{Hal}$ ini terlihat dari nilai rasio konversi pakan ikan mas M ustika yang secara nyata lebih rendah daripada ikan mas Majalaya. Nilai rasio konversi pakan yang relatif rendah menunjukkan bahwa populasi tersebut 
mampu secara efisien memanfaatkan pakan yang diberikan untuk pertumbuhan dan pembentukan biomassa.

Rendahnya kualitas lingkungan budidaya ikan di Waduk Darma dibandingkan lokasi lainnya dapat dilihat pada Tabel 3. Salah satu parameter perairan yang cukup berbeda di Waduk Darma adalah suhu minimal yang mencapai nilai $22,8^{\circ} \mathrm{C}$. Meskipun penetrasi sinar matahari di lokasi tersebut lebih jauh, namun suhu badan air pada kedalaman kurang dari satu meter pada waduk tersebut relatif lebih rendah. Hal ini diduga karena topografi Waduk Darma yang lebih tinggi dibanding lokasi lainnya, sehingga suhu perairannya menjadi lebih rendah. Suhu perairan yang mencapai nilai $22,8^{\circ} \mathrm{C}$ dapat memengaruhi performa ikan mas yang dibudidayakan (Boyd, 1990). Selain suhu, parameter utama kualitas air untuk kegiatan budidaya ikan mas, yaitu kandungan oksigen terlarut di Waduk Darma juga relatif lebih rendah dibanding lokasi lainnya. Secara lebih rinci, kualitas air media budidaya ikan mas di masing-masing lokasi disajikan pada Tabel 3.

Selain faktor-faktor utama di atas, kualitas air sebagai media budidaya ikan juga dipengaruhi oleh nilai $\mathrm{pH}$, kandungan amoniak, dan nitrit. Dilihat dari ketiga parameter tersebut, kondisi perairan di Waduk Darma menempati posisi paling rendah. Meskipun masih dalam batas toleransi, nilai pH perairan yang mencapai 5,0 diduga berpengaruh terhadap performa ikan budidaya (Ath-Thar et al., 2010). Demikian juga dengan kandungan amoniak dan nitrit yang mencapai nilai $0,8 \mathrm{mg} / \mathrm{L}$ dan $1 \mathrm{mg} / \mathrm{L}$ diduga menyebabkan penurunan performa ikan budidaya. Mustafa $\&$ Ratnawati (2013) menjelaskan bahwa kandungan amoniak sebesar 0,05-0,20 mg/L sudah menghambat pertumbuhan organisme akuatik pada umumnya. Selain itu, kandungan nitrit yang lebih dari $0,05 \mathrm{mg} / \mathrm{L}$ dapat bersifat toksik bagi organisme akuatik yang sangat sensitif.
Hasil pengujian performa budidaya menggunakan benih ikan mas Mustika yang secara nyata lebih baik daripada populasi pembanding di Waduk Darma mengindikasikan bahwa ikan mas Mustika mempunyai kemampuan lebih baik dalam merespons atau mentoleransi penurunan kondisi lingkungan. Pickering \& Pottinger (1989), Fevolden et al. (1992), Cnaani (2006), dan Debes et al. (2017) menjelaskan adanya kaitan yang erat antara resistansi terhadap penyakit dengan kemampuan menghadapi cekaman stres pada ikan. Ikan mas Mustika sebagai varietas unggul tahan penyakit KHV yang dibudidaya di dalam KJA di Waduk Darma ini mempunyai kemampuan yang baik dalam menghadapi cekaman lingkungan perairan yang bisa mengakibatkan stres pada ikan. Hasil pengujian ini didukung oleh penelitian Palimirmo et al. (2018) yang menunjukkan bahwa ikan mas Mustika mempunyai respons stres lebih baik dibanding ikan mas Majalaya.

\section{KESIMPULAN DAN SARAN}

Ikan mas Mustika mempunyai performa laju pertumbuhan, bobot individu, biomassa panen, dan nilai konversi pakan lebih baik daripada ikan mas pembanding (Majalaya). Ikan mas Mustika juga mempunyai kemampuan yang lebih tinggi dalam merespons atau mentoleransi kondisi perairan yang buruk daripada ikan mas pembanding (Majalaya).

Perlu kajian lebih mendalam terkait pengaruh genetik, lingkungan, dan interaksi keduanya terhadap penampilan fenotipik ikan mas Mustika. Kajian ini untuk mengevaluasi adaptabilitas dan stabilitas ikan mas Mustika pada lingkungan budidaya yang beragam, sehingga pemanfaatannya dapat lebih optimal.

\section{UCAPAN TERIMA KASIH}

Penelitian ini dibiaya oleh APBN melalui DIPA Tahun Anggaran 2013 pada Balai Riset Pemuliaan Ikan,

Tabel 3. Kualitas air media pemeliharaan pada uji multi lokasi ikan mas

Table 3. Water quality in the multi-location culture systems of common carp

\begin{tabular}{|c|c|c|c|c|}
\hline \multirow{2}{*}{$\begin{array}{c}\text { Parameter kualitas air } \\
\text { Water quality parameters }\end{array}$} & \multicolumn{4}{|c|}{ Lokasi pengujian (Trial locations) } \\
\hline & $\begin{array}{c}\text { KJA Jatiluhur } \\
\text { Jatiluhur net cage }\end{array}$ & $\begin{array}{c}\text { KJA Cirata } \\
\text { Cirata net cage }\end{array}$ & $\begin{array}{c}\text { KAD Tanjungsiang } \\
\text { Tanjungsiang running water }\end{array}$ & $\begin{array}{c}\text { KJA Darma } \\
\text { Darma net cage }\end{array}$ \\
\hline Kecerahan (Turbidity) (cm) & $35.8-58.8$ & $30.2-42.6$ & $40.3-60.6$ & $45.6-65.3$ \\
\hline Suhu (Temperature) $\left({ }^{\circ} \mathrm{C}\right)$ & $26.5-30.2$ & $27.0-30.0$ & $25.2-28.5$ & $22.8-26.8$ \\
\hline Oksigen terlarut (Dissolved oxygen ) (mg/L) & $4.0-6.2$ & $3.5-5.2$ & $2.8-4.8$ & $2.8-4.6$ \\
\hline Nilai pH (pH value) & $6.4-8.2$ & $6.5-8.5$ & $6.8-8.0$ & $5.0-7.8$ \\
\hline Amoniak (Ammonia ) (mg/L) & $0.0-0.8$ & $0.0-0.6$ & $0.0-0.3$ & $0.0-0.8$ \\
\hline Nitrit (Nitrite) (mg/L) & $0.0-0.9$ & $0.0-0.8$ & $0.0-0.6$ & $0.0-1.0$ \\
\hline
\end{tabular}


Sukamandi. Terima kasih disampaikan kepada semua peneliti dan teknisi yang terlibat selama kegiatan dilakukan. Selain itu, terima kasih dan penghargaan yang setinggi-tingginya juga disampaikan kepada semua pembudidaya yang terlibat dalam kegiatan uji multi lokasi ikan mas Mustika ini.

\section{DAFTAR ACUAN}

Ariyanto, D., Himawan, Y., Syahputra, K., Palimirmo, F.S., \& Suharyanto. (2019). Perbaikan karakter pertumbuhan ikan mas "Mustika” melalui seleksi. Jurnal Riset Akuakultur, 14(2), 71-76.

Ariyanto, D., Hayuningtyas, E.P., \& Syahputra, K. (2014). Respons seleksi individu karakter pertumbuhan populasi F-0 ikan mas strain Rajadanu. Jurnal Riset Akuakultur, 9(3), 353-361.

Ath-thar, M.H.F., Prakoso, V.A., Arifin, 0.Z., \& Gustiano, R. (2010). Performa pertumbuhan ikan nila BEST pada berbagai media pH. Prosiding Seminar Nasional Biologi 2010. Yogyakarta: Fakultas Biologi Universitas Gadjah Mada, hlm. 1085-1089.

Boyd, C.E. (1990). Water quality in pond for aquaculture. Alabama: Auburn University Press, 482 pp.

Cnaani, A. (2006). Genetic perspective on stress response and disease resistance in aquaculture. The Israeli Journal of Aquaculture, 58(4), 375-383.

Debes, P.V., Gross, R., \& Vasemägi, A. (2017). Quantitative genetic variation in, and environmental effects on, pathogen resistance, and temperaturedependent disease severity in a wild trout. The American Naturalist, 190(2), 244-265.

Fevolden, S.E., Refstie, T., \& Røed, K.H. (1992). Disease resistance in rainbow trout (Oncorhynchus mykiss) selected for stress response. Aquaculture, 104(1-2), 19-29.

Linhart, O., Gela, D., Rodina, M., Sjlechtov', V., \& Silechta, V. (2002). Top-crossing with paternal in heritance testing of common carp (Cyprinus carpio L.) progeny under two altitude conditions. Aquaculture, 204, 481-491.

Mustafa, A. \& Ratnawati, E. (2013). Karakteristik dan pengaruh faktor lingkungan terhadap produksi ikan bandeng (Chanos chanos) di tambak tanah sulfat masam Kabupaten Konawe Selatan Provinsi Sulawesi Tenggara. Jurnal Riset Akuakultur, 8(2), 325338.

Palimirmo, F.S., Syah putra, K., Himawan, Y., Ariyanto, D., \& Marnis, H. (2018). Performa ikan mas
(Cyprinus carpio) Mustika (Rajadanu tahan KHV) terhadap cekaman stress. Prosiding Seminar Nasional Ikan ke 10. Masyarakat Iktiologi Indonesia. Cibinong, 8-9 Mei 2018, hlm. 561-566.

Pickering, A.D. \& Pottinger, T.G. (1989). Stress responses and disease resistance in salmonid fish: Effects of chronic elevation of plasma cortisol. Fish Physiology and Biochemistry, 7(1-6), 253-258.

Purdom, C.E. (1993). Genetics and fish breeding. London: Chapman \& Hall. Fish and Fisheries, Series 8 , $277 \mathrm{pp}$.

Rakus, K.L., Wiegertjes, G.F., Adamek, M., Bekh, V., Stet, R.J.M., \& Irnazarow, I. (2008). Application of PCR-RF-SSCP to study major histocompatibility class II B polymorphism in common carp (Cyprinus carpio L.). Fish \& Shellfish Immunology, 24, 734-744.

Rukmono, D. (2005). Kebijakan Pengelolaan Kesehatan Ikan, Direktorat Kesehatan Ikan dan Lingkungan. Dalam Supriyadi, H. \& Priono, B. (Eds.). Strategi Pengelolaan dan Pengendalian Penyakit KHV. Jakarta: Pusat Riset Perikanan Budidaya, hlm. 1-6.

Syahputra, K., Palimirmo, S.P., Himawan, Y., \& Ariyanto, D. (2016). Performa ketahanan terhadap KHV ikan mas (Cyprinus carpio) Rajadanu hasil seleksi menggunakan marka molekuler CycaDAB1*05. Prosiding Forum Inovasi Teknologi Akuakultur 2016. Pusat Penelitian dan Pengembangan Perikanan. Surabaya, 25 April 2016, hlm. 919-924.

Sunarto, A., Rukyani, A., \& Itami, T. (2005). Indonesian experience on the outbreak of Koi Herpes Virus in koi and carp (Cyprinus carpio). Bull. Fish. Res. Agen., Supplement 2, 15-21.

Taukhid, Sunarto, A., Koesharyani, I., Supriyadi, H., \& Gardenia, L. (2005). Strategi pengendalian penyakit Koi Herpes Virus (KHV) pada ikan mas dan koi. Dalam Supriyadi, H. \& Priono, B. (Eds.). Strategi Pengelolaan dan Pengendalian Penyakit KHV. Jakarta: Pusat Riset Perikanan Budidaya, hlm. 11-60.

Tave, D. (1993). Genetic for fish hatchery managers. $2^{\text {nd }}$ ed. Connecticut: AVI. Publishing Company Inc., $418 \mathrm{pp}$.

Wang, C. \& Li, S. (2007). Genetic effects and genotype $><$ environment interactions for growthrelated traits in common carp, Cyprinus carpio L. Aquaculture, 272, 267-272. 